\title{
UPAYA PENINGKATAN PARTISIPASI MASYARAKAT DALAM PENCEGAHAN PENULARAN COVID-19 DAN OPTIMALISASI ADAPTASI KEBIASAAN BARU
}

\author{
Alfaina Wahyuni*, Rahmalika Fitri, M Zulfani Najmi, \\ Della Lovy, M Rafif, Afifatul Latifah \\ Universitas Muhammadiyah Yogyakarta \\ Corresponding author*: alfaina.wahyuni@umy.ac.id
}

\begin{abstract}
Since the start of the pandemic, the number of positive COVID-19 cases in DIY has been steadily increasing. This includes the Kasihan 2 Health Center in Bantul's work area. UMY Thematic Health KKN students identified several Covid-19-related issues. Based on the root cause analysis, four programs have been identified: (1) IT-based assistance and monitoring programs for COVID-19 survivors, (2) comorbid screening programs for the elderly population, (3) mentoring programs for COVID-19 survivors who have recovered, and (4) Covid-19 transmission prevention programs, vaccinations, and the implementation of new adaptations for health cadres and community volunteers. With this activity, it is hoped that patients will be able to live a happy isolation period, without appearing to be isolated and feeling cared for, so that immunity can be maintained and healed without sequelae, there is an increase in the knowledge of post-recovery patients so that they do not become infected again, and they can also become reliable educators and motivators for other communities. The gathering of information on the elderly with comorbidities. Furthermore, it is hoped that by optimizing the empowerment of health cadres and community volunteers, public awareness of the importance of adhering to health protocols during the new life during the COVID-19 pandemic will increase. Door-to-door comorbid screening activities cannot be carried out optimally because, according to the Covid-19 task force, they are too dangerous for students. In general, all activities went off without a hitch, with nearly $100 \%$ participation.
\end{abstract}

Keywords: Covid-19, Mentoring, Health Protocol,Ccomorbidity

\begin{abstract}
Abstrak
Sejak awal pandemi, jumlah kasus positif COVID-19 di DIY semakin bertambah dari hari ke hari. Termasuk di wilayah kerja Puskesmas Kasihan 2 Bantul. Beberapa masalah terkait Covid-19 berhasil diidentifikasi oleh mahasiswa KKN Tematik Kesehatan UMY. Berdasarkan analisis akar masalah maka program yang dijabarkan menjadi 4 yaitu (1) program pendampingan dan pemantauan penyintas covid-19 berbasis IT, (2) program skrining komorbid bagi penduduk lanjut usia, (3) program pendampingan paska sembuh penyintas covid-19 dan (4) program edukasi pencegahan penularan covid-19, vaksinasi dan penerapan adaptasi kebiasaan baru bagi kader kesehatan dan masyarakat relawan. Dengan kegiatan ini diharapkan penderita bisa menjalani masa isolasi dengan Bahagia, tanpa terkesan dikucilkan dan merasa diperhatikan sehingga imunitas bisa terjaga dan sembuh tanpa meninggalkan gejala sisa, terjadi peningkatan pengetahuan penderita pasca sembuh sehingga paska sembuh tidak terinfeksi lagi sekaligus bisa menjadi edukator dan motivator yang handal untuk masyarakat yang lain, terkumpulnya data masyarakat usia lanjut yang memiliki komorbid. Selain itu, diharapkan terjadi peningkatan kesadaran masyarakat terkait pentingnya mematuhi protokol kesehatan selama adaptasi kehidupan baru dimasa pandemi covid-19 melalui optimalisasi pemberdayaan kader kesehatan dan masyarakat relawan. Kegiatan skrining komorbid door to door tidak bisa dilaksanakan secara maksimal mengingat menurut satgas Covid-19 terlalu berisiko untuk mahasiswa. Secara umum semua kegiatan berjalan dengan lancar dengan tingkat partisipasi hampir 100\%.
\end{abstract}

Kata kunci: Covid-19, Pendampingan, Protokol Kesehatan, Komorbid

\section{Copyright (C) 2021, Alfaina Wahyuni, Rahmalika Fitri, M Zulfani Najmi, Della Lovy, M Rafif, Afifatul Latifah This is an open access article under the CC-BY NC-SA license http:// DOI 10.30656/ps2pm.v3i2.4084}




\section{PENDAHULUAN}

Coronavirus Disease 2019 (Covid19) merupakan permasalahan yang sangat serius yang saat ini sedang dihadapi di seluruh dunia. Covid-19 merupakan penyakit menular yang disebabkan oleh Virus Severe Acute Respiratory Syndrome Coronavirus 2 (SARS-CoV-2) dimana virus tersebut merupakan jenis virus baru (Sanders et al., 2020).

Sejak awal pandemi, jumlah kasus positif Covid-19 di DIY semakin bertambah dari hari ke hari, berdasarkan data dari Satuan Tugas Penanganan Covid-19 sampai dengan tanggal 12 Februari 2021 terdapat 24.812 kasus terkonfirmasi Covid-19 (Yogyakarta Tanggap COVID-19., 2021). Covid-19 yang berasal dari SARS-CoV-2 dapat menyerang siapa saja baik bayi, anak-anak, dewasa, maupun lansia (Jenie et al., 2020; Wati \& Manggala, 2020) dengan beragam manifestasi klinis yang ditimbulkan mulai dari gejala yang ringan seperti demam, batuk, sakit tenggorokan, malaise, dan mialgia hingga gejala yang berat seperti gagal ginjal, pneumonia dengan atau tanpa Acute Respiratory Distress Syndrome (ARDS), dan disfungsi multiorgan yang perlu penanganan lebih lanjut (Lotfi et al., 2020; Wati \& Manggala, 2020). Penyakit komorbid atau penyerta seperti hipertensi dan diabetes melitus, jenis kelamin lakilaki, usia lanjut dan juga perokok aktif termasuk faktor risiko SARSCoV-2 (Jenie et al., 2020; Novel Coronavirus COVID 19 Special Considerations for Pregnant Women.Docx., 2020; Sanders et al., 2020). Pandemi Covid-19 tentunya berdampak pada banyak aspek kehidupan baik kesehatan, ekonomi maupun sosiokultural masyarakat (Mutiarin et al., 2020). Masyarakat memiliki peran penting dalam memutus mata rantai penularan Covid-19 agar tidak menimbulkan sumber penularan baru (Profil Puskesmas - Puskesmas Kasihan 2., 2021). Upaya pencegahan terhadap peningkatan jumlah penderita Covid19, seperti yang sudah ditetapkan 
oleh WHO pada bulan Maret 2020 bahwa semua negara didesak untuk melakukan langkah-langkah efektif untuk mengurangi penularan. Oleh karena itu, tindakan pencegahan terhadap jenis penyakit menular tersebut wajib dilakukan secepat mungkin yang sesuai dengan Undang-Undang Nomor 6 Tahun 2018 yaitu tentang Kekarantinaan Kesehatan, dimana masyarakat perlu membatasi kegiatan sosial (Meri et al., 2020).

Prinsipnya pencegahan dan pengendalian Covid-19 di masyarakat dilakukan dengan 3M yaitu mencuci tangan dengan sabun, menjaga jarak dan memakai masker dimanapun serta meningkatkan imunitas tubuh dengan makan makanan bergizi dan rajin berolahraga (Chen et al., 2020; Coronavirus Disease 2019 (COVID-19) Treatment Guidelines., 2020; ProtokolKesehatan-COVID-19., 2020) serta vaksinasi (BeritaSatu.com., 2021; COVID-19 Vaccines., 2021; Kabar24, 2021) Survey pada 566 orang remaja, penerapan protokol kesehatan khususnya dalam pemakaian masker yang benar dan mencuci tangan yang benar masih belum sesuai yang diharapkan (Aini Q, 2020). Masih sangat diperlukan edukasi dan sosialisasi terkait Covid-19, penularan dan pencegahan melalui berbagai media (Maziyyah \& Rahajeng, 2020).

Puskesmas Kasihan II Bantul merupakan salah satu dari 26 Puskesmas yang ditunjuk sebagai tempat pelaksanaan KKN UMY periode Februari 2021 sekaligus sebagai wahana Pendidikan bagi mahasiswa Prodi Pendidikan Profesi Dokter Fakultas Kedokteran dan Ilmu Kesehatan Universitas Muhammadiyah Yogyakarta (FKIK UMY). Saat ini Puskesmas Kasihan II membawahi 2 desa binaan, yaitu Tirtonirmolo dan Ngestiharjo, dengan total rumah tangga sejumlah 17.176 rumah tangga. Berdasarkan data demografi yang ada, terdapat total 52.751 penduduk yang berada dibawah binaan Puskesmas Kasihan 
II (Profil Puskesmas - Puskesmas

Kasihan 2., 2021). Warga

masyarakatnya tergolong memilki

mata pencaharian yang beraneka ragam. Masyarakat yang paling banyak terdampak pandemi Covid19 adalah buruh pabrik, karyawan kantor, IRT, dan lansia. Hal ini tentunya menjadi tantangan tersendiri bagi Puskesmas untuk tetap dapat memberikan pelayanan yang maksimal meskipun dalam keterbatasan pandemi COVID-19.

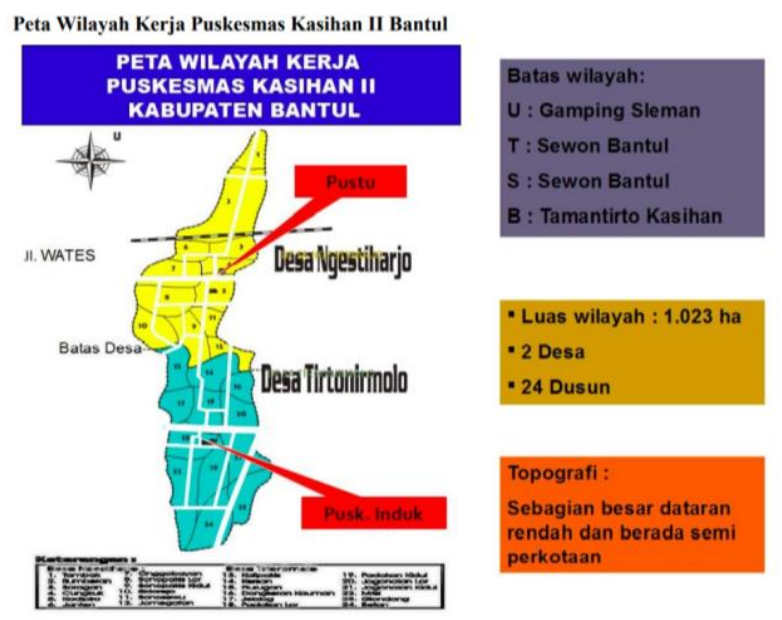

\section{Gambar 1. Peta Wilayah Kerja Puskesmas Kasihan II Bantul}

Melihat persebaran Covid-19 di kecamatan Kasihan, saat ini wilayah tersebut tengah tergolong dalam zona oranye, dengan jumlah pasien terkonfirmasi sebanyak 252 dirawat, 618 sembuh, dan 21 meninggal. Sedangkan jumlah kasus isolasi sebanyak 93 kasus. Pada wilayah kerja Puskesmas Kasihan II, diketahui bahwa kasus terbanyak untuk pasien terkonfirmasi Covid-19 mencapai 17 orang per hari dan saat kegiatan berlangsung terdapat 29 warga yang menjalani isolasi mandiri dirumah masing-masing. Berdasarkan rerata usia, penyintas merupakan warga dengan usia produktif (Yogyakarta Tanggap COVID-19., 2021). Mengingat adaptasi kehidupan baru di Indonesia sudah dimulai sejak lama (PROTOKOL PETUNJUK PRAKTIS LAYANAN KESEHATAN IBU ., 2020), tingginya angka kasus Covid- 
19 di wilayah tersebut mungkin disebabkan oleh karena kurang patuhnya masyarakat terhadap protokol kesehatan. Hal ini ditunjukkan dengan hasil observasi, bahwa masih banyak masyarakat yang tidak menggunakan masker dengan benar dan warga yang membentuk kerumunan. Oleh karena itu, diperlukan langkah pendekatan yang lebih intens dalam memantau kepatuhan masyarakat. Langkah ini ditujukan bagi seluruh warga, namun dalam program ini difokuskan kepada warga yang sedang dalam masa isolasi mandiri dan atau para penyintas Covid-19. Dari hasil diskusi dengan pimpinan Puskesmas dan Satgas Covid-19 puskesmas diperoleh informasi bahwa sosialisasi terkait dengan adaptasi kehidupan baru di masyarakat sudah dilakukan dan dinilai cukup efektif, tapi masih perlu ditingkatkan lagi. Sehingga perlu upaya peningkatan partisipasi masyarakat dalam hal pendampingan, pemantauan, dan penyaluran obat bagi pasien isolasi mandiri, edukasi dan penyuluhan kepada warga, serta skrining penyakit penyerta pada pasien lansia.

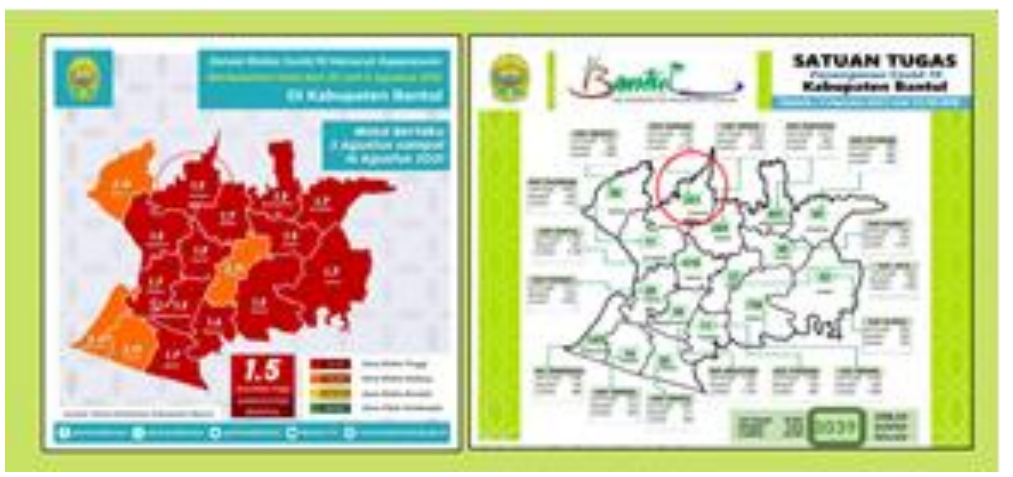

Gambar 2. Kasus Covid-19 di Kabupaten Bantul

Berdasarkan

dilapangan maupun wawancara

mendalam dengan Kepala Puskesmas dan Ketua Satgas Penanganan Covid19 Puskesmas Kasihan II, diidentifikasi permasalahan mitra sebagai berikut:

1. Peningkatan jumlah penderita Covid-19 di wilayah Puskesmas Kasihan II 
2. Sosialisasi terkait $\mathrm{AKB}$ sudah banyak dilakukan namun masih banyak pelanggaran terhadap penerapan protokol kesehatan

3. Stigma terkait penyintas Covid-19 masih banyak beredar dikalangan masyarakat, sehingga penyintas Covid-19 merasa dikucilkan.

4. Tingginya angka komorbid terutama penyakit metabolik kronik dan penyakit paru kronik khususnya pada penduduk lansia Sehingga dari latarbelakang dan analisis akar permasalahan, tujuan dari program pengabdian $\mathrm{KKN}$ Tematik diantaranya sebagai berikut:

1. Meningkatkan peran Puskesmas dalam pendampingan dan pemantauan pasien yang sedang dalam masa isolasi mandiri.

2. Meningkatkan pengetahuan dan kesadaran masyarakat terkait kesehatan dan adaptasi kehidupan baru selama masa pandemi Covid-19.

3. Mengetahui risiko-risiko komorbid pada pasien lanjut usia.
Dengan kegiatan diatas diharapkan: 1) lebih dari sama dengan $70 \%$ pasien yang sedang dalam masa isolasi mandiri mendapatkan pendampingan dengan baik, sehingga imunitas bisa terjaga dan sembuh tanpa meninggalkan gejala sisa, 2) terkumpulnya data masyarakat usia lanjut yang memiliki komorbid, 3) meningkatnya pengetahuan penderita pasca sembuh sehingga paska sembuh tidak terinfeksi lagi sekaligus bisa menjadi edukator dan motivator yang handal untuk masyarakat yang lain, dan 4) terdapat peningkatan kesadaran masyarakat terkait pentingnya mematuhi protokol kesehatan selama adaptasi kehidupan baru dimasa pandemi Covid-19.

\section{METODE PELAKSANAAN}

Berikut merupakan langkah-langkah program kegiatan, diantaranya sebagai berikut:

1. Koordinasi dengan pihak puskesmas untuk penentuan 
jadwal kegiatan, tehnis pelaksanaan dan PJ Kegiatan.

2. Persiapan alat, bahan, saranan dan prasarana.

3. Menghubungi pihak-pihak yang terkait dengan tiap kegiatan.

4. Melaksanakan kegiatan secara teliti, efektif dan efisien sehingga mencapai tujuan yang diharapkan. Adapun kegiatan yang dilakukan adalah :

a. Program pendampingan dan pemantauan penyintas Covid19

b. Program skrining komorbid bagi penduduk lanjut usia

c. Program pendampingan Paska Sembuh penyintas Covid-19

d. Program Edukasi Pencegahan Penularan Covid-19, Vaksinasi dan Penerapan Adaptasi Kebiasaan Baru bagi kader kesehatan dan masyarakat relawan

5. Evaluasi Kegiatan dan Rencana Tindak lanjut sehingga program selalu berkelanjutan. Bekerjasama dengan pihak puskesmas untuk monitoring agar kegiatan edukasi pencegahan penularan Covid-19, sosialisasi vaksinasi dan penerapan $\mathrm{AKB}$ terutama oleh kader kesehatan dan masayarakat relawan selalu berjalan dengan baik dan efisien.

6. Pelaporan. Dilakukan penyusunan laporan kegiatan, video kegiatan, dan penyusunan artikel publikasi untuk seminar nasional maupun jurnal nasional. Luaran tambahan dari kegiatan ini adalah bekerjasama dengan mitra untuk menyusun dan mencetak Buku Saku Pendampingan Pasca Sembuh Penyintas Covid-19.

\section{HASIL DAN PEMBAHASAN}

Sebagian besar program kerja adalah selaras dengan program pokok Puskesmas yang dalam pelaksanannya banyak dibantu oleh mahasiswa KKN. Mahasiswa KKN terlibat aktif dalam semua tahap kegiatan termasuk terjun langsung ke 
masyarakat dengan menerapkan protokol Kesehatan secara ketat.

1. Program pendampingan dan pemantauan penyintas Covid-19

Sasaran dari kegiatan ini adalah warga yang terkonfirmasi Covid-19 yang menjalani isolasi mandiri dirumah masing masing. Data dari puskesmas menunjukkan ada 29 warga. Kegiatan pendampingan dilakukan secara daring menggunakan social media berupa aplikasi Whatsapp. Setiap hari mahasiswa menyapa, memonitor gejala dan memberikan informasi grafis terkait Covid-19 secara online pada pasien. Disamping itu mahasiswa juga membantu menyalurkan obat dan vitamin dari puskesmas. Beberapa warga yang isoman juga aktif berkonsultasi tentang gejala yang mereka keluhkan. Jika ada keluhan yang berat diteruskan ke dokter puskesmas untuk ditindaklanjuti. Dari 29 warga yang mengalami isoman, semuanya merespon dengan baik. Hanya saja ada 5 orang warga karena sudah tua mereka merespon dengan dibantu keluarga yang sedang isoman juga.

2. Program pendampingan Paska Sembuh penyintas Covid-19

Kegiatan ini merupakan lanjutan dari kegiatan pendampingan warga yang terkonfirmasi positif. Setelah menjalani isoman, warga diwajibkan untuk mengisi kuesioner yang disusun oleh tim KKN dan satgas Covid-19 dalam bentuk kuesioner online. Jika ada warga yang tidak berkenan, bisa mengisi secara luring. Kuesioner berisi tentang keluhan dan gejala saat ini serta kesan-kesan selama menjalani isoman yang didampingi oleh mahasiswa KKN. Dari 29 warga isoman semuanya mengisi kuesioner baik secara daring maupun luring, 25 warga (86\%) menyatakan senang karena sudah didampingi selama isoman dan berharap kegiatan ini bisa dilanjutkan. Bagi warga yang sudah memenuhi kriteria kesembuhan secara klinis, diberikan $e$-Book berupa Buku Saku Pendampingan Pasca Sembuh Bagi Penyintas Covid-19 
agar tidak terjangkit Covid-19 kembali, bisa mengenali gejala post

Covid-19 dan diharapkan bisa menjadi educator dan motivator bagi warga yang lain.

3. Program skrining komorbid bagi penduduk lanjut usia

Kegiatan ini sangat penting mengingat jumlah penduduk lansia cukup banyak. Kegiatan dilakukan melalui posyandu lansia dan kunjungan (door to door) bagi lansia yang tidak hadir pada saat posyandu. Skrining dan pemeriksaan kesehatan lansia meliputi anamnesis terkait komorbid yang diderita misalnya hipertensi, penyakit diabetes mellitus, penyakit jantung dan lainlain; penimbangan berat badan,
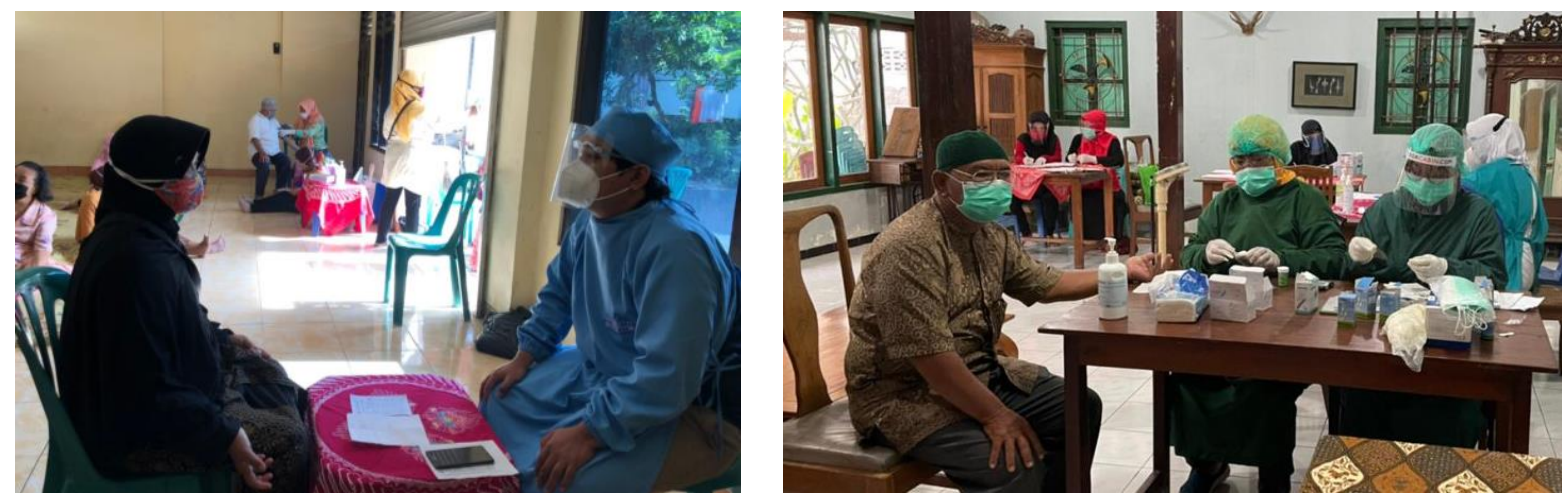

Gambar 3. Program Posyandu dan skrining komorbid pada pasien lansia

4. Program Edukasi Pencegahan Penularan Covid-19, Vaksinasi pengukuran tekanan darah, pemeriksaan fisik umum. Kegiatan posyandu lansia dihadiri oleh 19 orang dan 15 diantaranya ditemukan komorbid berupa hipertensi, obesitas dan diabetes mellitus. Respon mereka sangat baik dan antusias untuk berkonsultasi. Dengan kegiatan ini bisa dipetakan jenis komorbid pada lansia sehingga bisa diantisipasi agar tidak sampai tertular Covid-19 atau jika terjangkit kondisi tidak parah. Selain itu bagi mahasiswa sendiri kegiatan ini bisa menjadi media belajar komunikasi dan edukasi langsung kepada masyarakat dengan karakter yang bervariasi

(Gambar 3). 
kesehatan dan masyarakat

relawan

Program-program tambahan yang diharapkan dapat memiliki efek jangka panjang diantaranya adalah program edukasi masyarakat dan pelatihan kader kesehatan. Program edukasi dilakuan melalui media sosial, edukasi melalui poster, leaflet, dan buku saku pasca Covid-19 yang kemudian disalurkan kepada
Puskesmas dalam bentuk softfile dan hardfile. Pemberian softfile ini dimaksudkan agar dapat digunakan dengan lebih mudah oleh pihak mitra, mengingat kondisi pandemi yang meningkat sehingga memanfaatkan media sosial di kalangan masyarakat untuk sosialisasi terkait Covid-19 (Gambar $4)$.

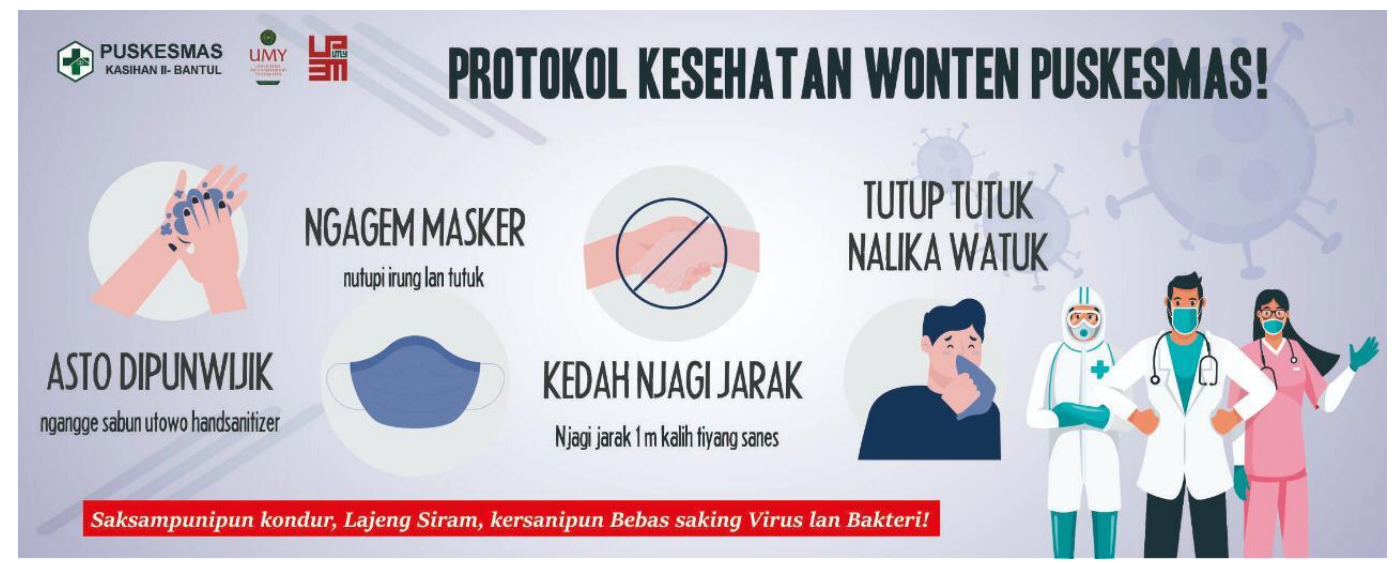

Gambar 4. Edukasi kesehatan dengan menggunakan beberapa media berupa poster
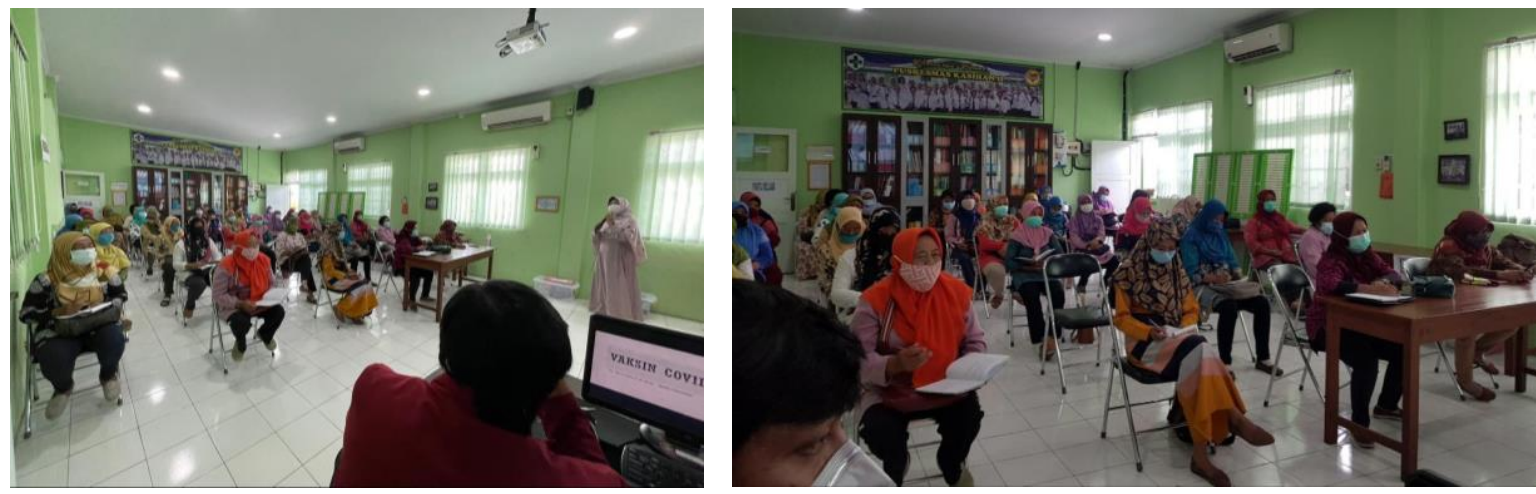

Gambar 5. Pelatihan kader kesehatan masyarakat dilakukan dalam bentuk Sarasehan 
Sedangkan pada program pelatihan kader kesehatan, dengan mengusung tema vaksinasi, dengan narasumber salah satu dosen bagian Ilmu Penyakit Dalam FKIK UMY diharapkan dapat menjadi bekal bagi para kader dalam memberikan sosialisasi yang baik dan benar kepada masyarakat binaanya tentang pentingnya vaksinasi, siapa saja yang harus vaksinasi, efek samping yang mungkin timbul serta pertolongan pertama jika timbul efek samping akibat vaksinasi (Gambar 5). Kegiatan ini dilakukan secara luring di aula puskesmas dan diikuti oleh 37 kader Kesehatan dari 40 orang jumlah kader di puskesmas (92,5\%). Untuk melihat apakah ada peningkatan pengetahuan dilalukan pretest dan postest. Dari hasil kuesioner, terdapat peningkatan pengetahuan tentang Covid-19, pencegahan dan vaksinasinya sebesar 45\%. Hasil pretest didapatkan 40,5\% responden mempunyai pengetahuan yang baik, sedangkan hasil postest meningkat menjadi $86,5 \%$. Para kader juga sangat antusias bertanya pada saat sesi diskusi.

Proses evaluasi kinerja pelaksanaan program pengabdian secara keseluruhan dilakukan pada akhir pelaksanaan kegiatan dalam acara monitoring dan evaluasi program secara luring di Aula Puskesmas. Diikuti oleh Kepala Puskesmas, Dokter Pendamping Mahasiswa, Koordinator Satgas Covid-19 Puskesmas, Wakil Kader Kesehatan, Dosen Pengabdi dan mahasiswa KKN. Dalam acara tersebut, mahasiswa KKN melakukan presentasi capaian kegiatan dan kendala yang terjadi di lapangan. Secara umum, kegiatan pengabdian masyarakat ini berjalan dengan lancar dengan capaian 100\%. Pendampingan dan pemantauan penyintas Covid-19 yang menjalan isolasi mandiri berjalan dengan cukup efektif. Hal tersebut dilihat dari respon yang sangat antusias dari para penyintas Covid-19 melalui whatsapp ke mahasiswa KKN. Program edukasi berjalan cukup 
baik, baik edukasi terhadap pasien Covid-19 yang sedang dalam masa isolasi mandiri maupun terhadap pasien lansia. Pasien Covid-19 sangat ambisius menyampaikan hal yang dirasakan ketika isolasi mandari. Posyandu dan skrining komorbid pada pasien lansia bisa berjalan cukup baik. Meskipun ada kendala dilapangan, dengan kerjasama yang baik dengan pihak mitra dan kaderkader kesehatan. Kegiatan posyandu lansia ini sangat bermanfaat dan dinilai cukup memberi andil besar, dimana antusias para lansia terlihat dari apa yang disampaikan melalui pertanyaan kepada mahasiswa KKN. Seminar sosialisasi peran vaksin bagi kader kesehatan yang diselenggarakan bekerja sama dengan pihak mitra berjalan dengan cukup baik. Partipasi kader dalam kegiatan cukup tinggi dan para kader juga sangat antusias pada saat berdiskusi dengan narasumber.

Evaluasi dilakukan dengan pendekatan Analisis Input-ProcessOutput-Outcome. Secara umum program sudah terlaksana dengan baik sesuai input yang ada, ditunjukkan dengan output yang baik berupa hasil pre dan postes, hasil kuesioner pasien penyintas maupun kesan umum dari masyarakat maupun pihak mitra. Namun hubungan baru terwujud baru antara Input-Process-Output dan belum sampai pada hubungan outcome (dampak) yaitu belum tampak adanya peningkatan kesadarandan partisipasi masyarakat dalam pencegahan penularan Covid-19. Kondisi ini karena waktu program pengabdian yang pendek. Oleh karena itu masih diperlukan tindak lanjut untuk meningkatkan dampak positif program-program pengabdian diatas.

\section{SIMPULAN}

Secara umum semua kegiatan berjalan dengan lancar dengan tingkat partisipasi hampir 100\% serta terjadi peningkatan pengetahuan tentang Covid-19, pencegahan dan vaksinasinya. Respon masyarakat 
dan mitra sangat baik. Oleh karena waktu kegiatan yang pendek, keberhasilan baru sampai tahap output dan belum terlihat pada dampak berupa peningkatan kesadaran masyarakat secara umum dalam hal pencegahan Covid-19. Masih diperlukan tindak lanjut agar dampak positif semakin besar. Pihak masyarakat dan mitra mempunyai harapan besar agar kegiatan ini berkelanjutan. Pendampingan warga yang isoman secara daring perlu dilanjutkan oleh kader Kesehatan maupun menjadi kegiatan para mahasiswa Program Profesi Dokter FKIK UMY. Perlu peningkatan pemberdayaan kader Kesehatan sebagai educator dan motivator bagi masyarakat teutama tentang vaksinasi dan meningkatkan kedisiplinan dalam menjaga protokol kesehatan pencegahan Covid-19. Kader Kesehatan juga perlu dilibatkan dalam pendampingan warga lansia yang mempunyai komorbid sehingga jika ada gejala bisa segera ditangani pihak puskesmas.

\section{UCAPAN TERIMA KASIH}

Ucapan terima kasih terutama kepada pihak LP3M program KKNPPM dan Puskesmas Kasihan II Bantul sebagai mitra Program KKN Tematik Kesehatan 23.

\section{REFERENSI}

Aini Q. (2020). Survei Perilaku Masyarakat Indonesia saat Masa Pandemi Covid-19. http:// repository.umy.ac.id/bitstream/ha ndle/123456789/34569/Ariket\%2 0Covid-19.jpeg? sequence $=$ 1EisAllowed $=y$

BeritaSatu.com. (2021, February 6). Menkes Sebut Tujuan Vaksinasi Covid-19 untuk Bentuk Herd Immunity. Beritasatu.Com. https ://www.beritasatu.com/kesehatan/ 725823/menkes-sebut-tujuanvaksinasi-covid19-untuk-bentukherd-immunity

Chen, H., Guo, J., Wang, C., Luo, F., Yu, X., Zhang, W., Li, J., Zhao, D., $X u, D$., Gong, Q., Liao, J., Yang, H., Hou, W., \& Zhang, Y. (2020). Clinical characteristics and intrauterine vertical transmission potential of COVID-19 infection in nine pregnant women: $A$ 
retrospective review of medical records. The Lancet, 395(10226), 809-815. https://doi.org/10. 1016/S0140-6736(20)30360-3

Coronavirus Disease 2019 (COVID-19) Treatment Guidelines. (2020).

COVID-19 vaccines. (2021, June 30). https://www.who.int/emergencies /diseases/novel-coronavirus2019/covid-19-vaccines

Jenie, I. M., Noor, Z., Husna, M. U., Herjuna, M., E Perdana, L. P. (2020). Pemberdayaan Kader Posyandu Lansia Pada Masa Pandemi Covid-19. Prosiding Seminar Nasional Program Pengabdian Masyarakat. https://doi.org/10.18196/ppm.32. 178

Lotfi, M., Hamblin, M. R., E Rezaei, N. (2020).

COVID-19: Transmission, prevention, and potential therapeutic opportunities. Clinica Chimica Acta; International Journal of Clinical Chemistry, 508, 254266.

https://doi.org/10.1016/j.cca.2020 .05 .044

Maziyyah, N., E Rahajeng, B. (2020). Edukasi Covid-19 Melalui Media Buku Pintar Bagi Guru Dan Orang Tua Tk Aba Ponggalan, Giwangan. Prosiding Seminar Nasional Program Pengabdian Masyarakat. https://doi.org/10.18196/ppm.35. 97

Meri, M., Khusnul, K., Mardiana, U., \& Nurpalah, R. (2020). Bantenese Jurnal Pengabdian Masyarakat. 2,8 .

Mutiarin, D., Atmojo, M. E., E Zulfikar, M. H. (2020). MENYIAPKAN KELUARGA BERDAYA DASAWISMA DI MASA PANDEMI COVID-19. Prosiding Seminar Nasional Program Pengabdian Masyarakat. https://doi.org/10.18196/ppm.34. 297

Novel Coronavirus COVID 19 special Considerations for Pregnant Women.docx. (2020).

Profil Puskesmas - Puskesmas Kasihan 2. (2021, February 12). https://puskesmas.bantulkab.go.id /kasihan2/profil-puskesmas/

Protokol Petunjuk Praktis Layanan Kesehatan Ibu .pdf. (2020).

Protokol-Kesehatan-COVID-19.pdf. (2020).

Sanders, J. M., Monogue, M. L., Jodlowski, T. Z., E Cutrell, J. B. (2020). Pharmacologic Treatments for Coronavirus Disease 2019 (COVID-19): A Review. $J A M A$. 
https://doi.org/10.1001/jama.2020 .6019

Soal Vaksin Covid-19, Muhammadiyah Sampaikan 5 Rekomendasi । Kabar24. (2021, January 6). Bisnis.Com. https://kabar 24.bisnis.com/read/20210106/15/ 1339265/soal-vaksin-covid-19muhammadiyah-sampaikan-5rekomendasi
Wati, D. K., E Manggala, A. K. (2020). Overview of management of children with COVID-19. Clinical and Experimental Pediatrics, 63(9), 345-354. https://doi.org/10.3345/cep.2020. 00913

Yogyakarta Tanggap COVID-19. (2021, February 12). Informasi Covid-19 Daerah Istimewa Yogyakarta. https://corona.jogjaprov.go.id/dat a-statistik 